\title{
AKTIVITAS EKSTRAK DAUN SALAM (EUGENIA POLYANTHA) SEBAGAI ANTIINFLAMASI PADA TIKUS PUTIH (RATTUS NORVEGICUS)
}

\author{
Risna Agustina*, Dewi Tita Indrawati, Muhammad Amir Masruhin \\ Laboratorium Penelitian dan Pengembangan FARMAKA TROPIS Fakultas Farmasi \\ Universitas Mulawarman, Samarinda, Kalimantan Timur \\ *email: risna@farmasi.unmul.ac.id
}

\begin{abstract}
The aim of this study was to determine the anti inflammatory effect of ethanol extract of salam leaves, viewed from decrease paw edema volume rats carrageenan induced 1\%. For the anti-inflammatory activity measurement, five different groups were established, three test group, one positive control group and one negative control group. In the test group given the extract of salam leaves, the positive control given Na diklofenak, while the negative control group given $\mathrm{Na} C M C$. Salam leaf extract was administered in three different doses : $50 \mathrm{mg} / \mathrm{kgBB}, 150 \mathrm{mg} / \mathrm{kgBB}$ and $250 \mathrm{mg} / \mathrm{kgBB}$. Each of them were given orally 30 min before carrageenan induced. The paw volume was measured every hour for five hour after injection carrageenan. The results showed that ethanol extract of salam leaves in all doses has anti inflammatory efect on white rats.
\end{abstract}

Keywords: Anti-inflammatory, extract salam leaves, white rats

\begin{abstract}
ABSTRAK
Penelitian ini bertujuan untuk mengetahui efek antiinflamasi ekstrak etanol daun salam ditinjau dari penurunan volume udem telapak kaki tikus putih jantan yang diinduksi karagenan 1\%. Untuk pengukuran aktivitas antiinflamasi digunakan 5 kelompok hewan coba yang berbeda yakni 3 kelompok uji, 1 kelompok kontrol positif dan 1 kelompok kontrol negatif. Pada kelompok uji diberikan ekstrak daun salam, pada kontrol positif diberikan $\mathrm{Na}$ diklofenak, sedangkan pada kelompok kontrol negatif diberikan $\mathrm{Na} \mathrm{CMC}$. Pemberian ekstrak daun salam dilakukan 3 variasi dosis yaitu dosis $50 \mathrm{mg} / \mathrm{kgBB}$, $150 \mathrm{mg} / \mathrm{kgBB}$, dan $250 \mathrm{mg} / \mathrm{kgBB}$. Bahan uji diberikan secara oral 30 menit sebelum diinduksi dengan $0,1 \mathrm{~mL}$ karagenan $1 \%$. Pengukuran volume telapak kaki tikus dilakukan setiap jam selama 5 jam setelah induksi karagenan. Hasil penelitian menunjukkan ekstrak etanol daun salam pada semua variasi dosis memberikan efek antiinflamasi pada tikus putih jantan.
\end{abstract}

Kata kunci: Antiinflamasi, ekstrak daun salam, tikus putih jantan,

\section{PENDAHULUAN}

Indonesia kaya akan tanaman yang berkhasiat sebagai obat. Penelitian terhadap tanaman yang berkhasiat sebagai obat terus dilakukan. Salah satu tanaman yang sering digunakan masyarakat yaitu daun salam. Telah banyak dilakukan penelitian untuk mengetahui khasiat daun salam sebagai obat tradisional. Manfaat daun salam diantaranya sebagai anti bakteri, terapi hipertensi, diabetes, asam urat, diare dan hiperlipidemia [1].

Daun salam (Eugenia polyantha) adalah salah satu jenis rempah-rempah yang sudah tidak asing lagi bagi sebagian besar masyarakat Indonesia. Daun salam sendiri saat ini banyak dimanfaatkan sebagai bahan pelengkap dan penyedap alami pada masakan karena aromanya 
yang khas. Namun, selain manfaatnya sebagai penyedap makanan, daun salam juga menyimpan manfaat lain bagi kesehatan tubuh kita yang tidak kita ketahui.

Inflamasi merupakan suatu respon protektif normal terhadap luka jaringan yang disebabkan oleh trauma fisik, zat kimia yang merusak atau zat-zat mikrobiologik. Inflamasi adalah usaha tubuh untuk menginaktivasi atau merusak organisme yang menyerang, menghilangkan zat iritan, dan mengatur derajat perbaikan jaringan [2].

Kandungan kimia daun salam diantaranya yaitu flavonoid. Dari berbagai jurnal diketahui bahwa flavonoid dapat digunakan sebagai antiinflamasi. Aktivitas antiinflamasi flavonoid dengan penghambatan siklooksigenase atau lipooksigenase [3]. Berdasarkan uraian di atas diketahui belum adanya informasi yang lengkap mengenai efek farmakologi daun salam sebagai anti inflamasi maka dilakukan penelitian aktivitas antiinflamasi pada ekstrak daun salam.

\section{METODE PENELITIAN}

\section{Bahan}

Bahan yang digunakan dalam penelitian adalah simplisia daun salam, etanol 70\%, karagenan, $\mathrm{NaCl}$ fisiologis $0,9 \%$, Natrium diklofenak, Na CMC dan akuades.

Hewan percobaan yang digunakan adalah tikus putih jantan berumur 3 bulan dengan berat 180-240 gram dan sehat.

\section{Peralatan}

Alat-alat yang digunakan dalam penelitian ini adalah alat untuk maserasi, rotary evaporator, pletismometer, waterbath, timbangan analitis, inkubator, cawan porselin, spoid, sonde, labu ukur dan alat gelas penunjang lainnya.

\section{Prosedur}

\section{Pengumpulan Sampel}

Daun salam diambil pada sore hari dengan cara dipotong dari ranting pohon. Dilakukan sortasi basah pada daun salam untuk memisahkan kotoran-kotoran yang terdapat pada daun. Daun dicuci dengan air mengalir untuk menghilangkan pengotor yang melekat pada daun. Dirajang daun salam untuk mempermudah proses pengeringan dan ekstraksi. Dilakukan sortasi kering untuk menghilangkan pengotor yang masih tertinggal pada daun. Kemudian ditimbang berat simplisia kering daun salam yang dihasilkan.

\section{Ekstraksi}

Daun salam diekstraksi dengan cara maserasi menggunakan pelarut etanol $70 \%$ selama 3-5 hari. Disaring menggunakan kertas saring dan ditampung didalam wadah. Kemudian dipekatkan menggunakan rotary evaporator dan dikeringkan diatas waterbath untuk mendapatkan ekstrak daun salam.

\section{Persiapan hewan uji}

Semua hewan uji dipelihara dalam kondisi yang sama. Sebelum digunakan tikus diadaptasikan dengan lingkungan penelitian selama dua minggu dan sebelum pemberian perlakuan, tikus dipuasakan \pm 18 jam dengan tetap diberi minum.

\section{Pengujian Aktivitas Antiinflamasi}

Dibagi tikus menjadi lima kelompok dengan jumlah tikus masingmasing kelompok 5 ekor. Diberi tanda pada mata kaki tikus lalu diukur terlebih dahulu kaki tikus menggunakan pletismometer dengan cara mencelupkan kaki tikus ke dalam bejana hingga tanda batas. Pada setiap pengukuran tinggi cairan pada alat harus sama. 
Perlakuan yang diberikan pada masing-masing kelompok adalah

- Kontrol negatif suspensi Na CMC 1\%

- Kontrol positif suspensi obat $\mathrm{Na}$ diklofenak $50 \mathrm{mg}$

- Kelompok uji 1; ekstrak etanol daun salam $50 \mathrm{mg} / \mathrm{kgBB}$

- Kelompok uji 2; ekstrak etanol daun salam $150 \mathrm{mg} / \mathrm{kgBB}$

- Kelompok uji 3; ekstrak etanol daun salam $250 \mathrm{mg} / \mathrm{kgBB}$

Dibersihkan kaki tikus dengan alkohol setelah 30 menit, kemudian disuntik kaki tikus dengan karagenan secara intraplantar $0,1 \mathrm{~mL}$. Diukur kaki tikus setelah 1 jam pemberian karagenan selama 5 jam tiap 1, 2, 3, 4 dan 5 jam. Kemudian diukur volume udem telapak kaki masing-masing tikus dengan pletismometer.

\section{HASIL DAN PEMBAHASAN}

\section{Aktivitas Antiinflamasi Ekstrak Daun Salam}

Pengukuran volume udem pada telapak kaki tikus dilakukan setiap satu jam selama 5 jam setelah telapak kaki tikus dibuat radang dengan induksi karagenan. Pengamatan selama 5 jam dilakukan untuk mengetahui waktu dimana volume radang maksimal terbentuk. Pada penelitian ini, volume radang rata-rata kelompok kontrol negatif meningkat mulai jam pertama sampai jam kelima, dimana volume radang terbesar terjadi pada jam kelima.

Tabel 1. Volume radang rata-rata telapak kaki tikus

\begin{tabular}{cccccc}
\hline \multirow{2}{*}{ Perlakuan } & \multicolumn{5}{c}{ Volume radang jam ke- } \\
\cline { 2 - 6 } & 1 & 2 & 3 & 4 & 5 \\
\hline $50 \mathrm{mg} / \mathrm{kgBB}$ & 0,13 & 0,21 & 0,28 & 0,21 & 0,16 \\
$150 \mathrm{mg} / \mathrm{kgBB}$ & 0,11 & 0,20 & 0,29 & 0,20 & 0,13 \\
$250 \mathrm{mg} / \mathrm{kgBB}$ & 0,19 & 0,30 & 0,30 & 0,27 & 0,23 \\
Na Diklofenak & 0,08 & 0,24 & 0,19 & 0,18 & 0,16 \\
Na CMC & 0,22 & 0,30 & 0,32 & 0,34 & 0,38 \\
\hline
\end{tabular}

Penelitian Ravi 2009) dan Linnet (2010) menunjukkan bahwa waktu terbentuknya radang akibat dari induksi karagenan terdiri dari dua fase yaitu 1-2 jam setelah injeksi karagenan, menyebabkan trauma akibat radang yang ditimbulkan oleh karagenan. Pada fase pertama terjadi pelepasan serotonin dan histamin ke tempat radang serta terjadi peningkatan sintesis prostaglandin pada jaringan yang rusak. Pada fase kedua terjadi pelepasan prostaglandin dan dimediasi oleh bradikinin, leukotrien [4].

Dari hasil penelitian menunjukkan bahwa ketiga variasi dosis ekstrak etanol daun salam mampu menghambat radang. Volume radang pada telapak kaki tikus yang lebih kecil dari kelompok kontrol negatif menunjukkan bahwa ekstrak etanol daun salam mampu menekan radang yang disebabkan oleh karagenan. Tampak adanya perbedaan volume radang antara kelompok kontrol negatif dan dosis ekstrak etanol daun salam. Pada kelompok kontrol negatif yang diberikan $\mathrm{Na} \mathrm{CMC}$, volume radang meningkat mulai dari jam pertama sampai jam kelima, sedangkan pada kelompok perlakuan dosis $50 \mathrm{mg} / \mathrm{kgBB}, \quad 150$ $\mathrm{mg} / \mathrm{kgBB}$ dan $250 \mathrm{mg} / \mathrm{kgBB}$, peningkatan volume radang mulai terjadi pada jam pertama sampai jam ketiga dan mulai mengalami penurunan pada jam keempat. 


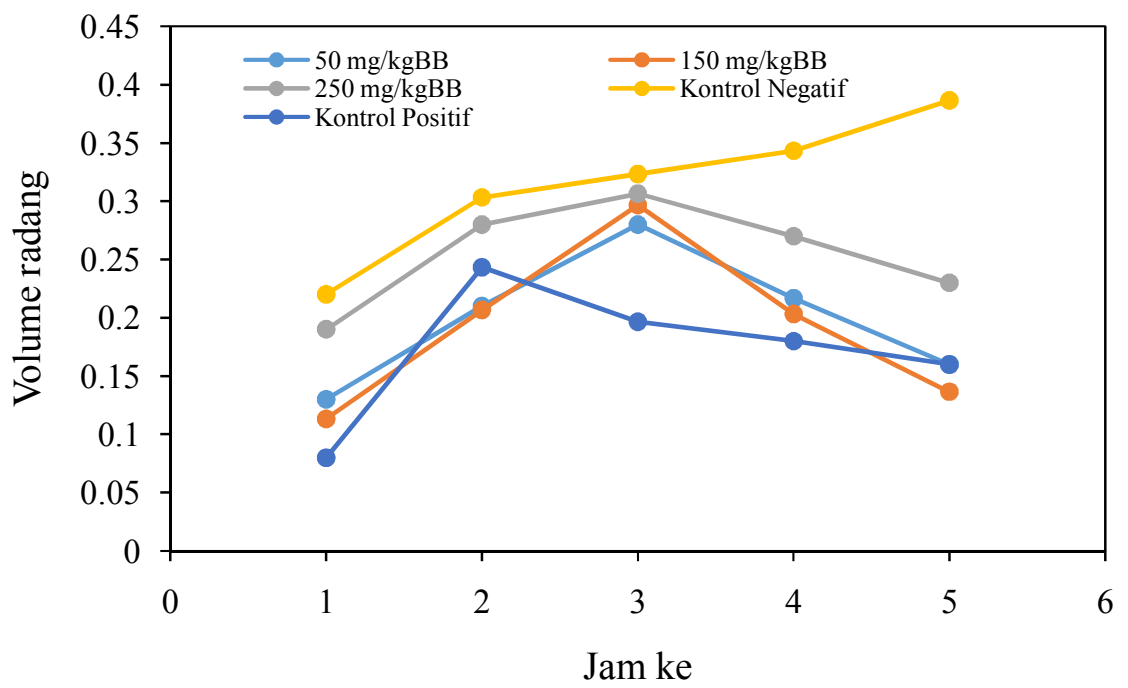

Gambar 1. Volume radang rata-rata telapak kaki tikus

Aktivitas antiinflamasi ekstrak daun salam lebih kecil bila dibandingkan dengan $\mathrm{Na}$ diklofenak. Volume radang pada kelompok Na diklofenak meningkat mulai dari jam pertama dan menurun pada jam ketiga. Aktivitas antiinflamasi ekstrak daun salam diperkirakan berkaitan dengan penghambatan pembentukan siklooksigenase. Flavonoid adalah senyawa yang diduga berperan memiliki efek antiinflamasi dalam ekstrak daun salam yang mekanisme kerjanya diduga menghambat jalur siklooksigenase pada jalur metabolisme asam arakidonat.

\section{KESIMPULAN}

Ekstrak etanol daun salam dosis 50 $\mathrm{mg} / \mathrm{kgBB}, \quad 150 \mathrm{mg} / \mathrm{kgBB}$ dan 250 $\mathrm{mg} / \mathrm{kgBB}$ memiliki aktivitas antiinflamasi pada tikus putih yang diinduksi karagenan, dimana volume radang yang terjadi mengalami penurunan pada jam keempat.

\section{DAFTAR PUSTAKA}

1. Utami, P. 2013. The Miracle of Herbs. Agromedia Pustaka: Jakarta.

2. Mycek, M. J. 2001. Farmakologi: Ulasan Bergambar. Widya Medika: Jakarta.

3. Hidayati, N. A., Listyawati, S dan Setyawan, A. D. 2005. Kandungan Kimia dan Uji Anti Inflamasi Ekstrak Etanol Lantana camara L. Pada Tikus Putih (Rattus novergicus L.) Jantan. Jurnal Bioteknologi. 5. (1).

4. Hasanah, Aliya Nur. Analisis Kandungan Minyak Atsiri dan Uji Aktivitas Antiinflamasi Ekstrak Rimpang Kencur (Kaempferia galanga L.) Jurnal Matematika dan Sains. 16. (3). 